\title{
Standardization of PCR and sequencing-based methods for the detection of the presence of CP4 EPSPS gene in Zea mays
}

Carlos Humberto Chamone Cangussu ${ }^{1}$, Léia Cardoso ${ }^{2}$, Alessandra Rejane Ericsson de Oliveira Xavier ${ }^{3 *}$, Josiane dos Santos ${ }^{4}$, Luiz Felipe Lopes Campos ${ }^{5}$, Murilo Malveira Brandão ${ }^{6}$, Denys Cunha Fonseca Garcia ${ }^{7}$, Alexandre Moisés Ericsson de Oliveira ${ }^{8}$, Evandrei Santos Rossi ${ }^{9}$, Mauro Aparecido de Sousa Xavier10 ${ }^{10}$

DOI: https://doi.org/10.35699/2447-6218.2020.19990

\begin{abstract}
With the rise in planting of transgenic cultivars in Brazil as well as worldwide, the demand for legal regulations has increased. The transgenic event MON88017 is often found in maize cultivars marketed in Brazil. The event contains the CP4 EPSPS and cry3Bb1 genes, which encode tolerance to the herbicide glyphosate and resistance to caterpillars, respectively. Globally, methodologies to track transgenic events are mandatory. The objective of this study was to standardize a method based on qualitative PCR and sequencing for detection of the CP4 EPSPS gene in Zea mays. DNA was extracted from three commercial strains of transgenic maize, containing the MON88017 event, as well as conventional maize. Primers were designed for partial detection of the zein and CP4 EPSPS genes. PCR reactions were performed for detection of partial regions of CP4 EPSPS and Zein (as endogenous marker of Z. mays) genes. The three transgenic maize inbred lines tested positive for Zein and CP4 EPSPS, and the two conventional strains tested negative for CP4 EPSPS and positive for the Zein gene. To confirm the presence of the genic regions, PCR products were sequenced and showed 100\% identity with sequences of Zein and CP4 EPSPS genes deposited in GenBank. Thus, the results of this study suggest the applicability of an 'in-house' method for the qualitative detection of CP4 EPSPS in genetically modified maize cultivars.
\end{abstract}

Keywords: Genetically modified organisms. MON88017. Detection. Maize

\footnotetext{
${ }^{1}$ State University of Montes Claros, Montes Claros, MG, Brazil. https://orcid.org/0000-0002-4487-6130.

${ }^{2}$ State University of Montes Claros, Montes Claros, MG, Brazil. https://orcid.org/0000--0002-4605-6160.

${ }^{3}$ State University of Montes Claros, Montes Claros, MG, Brazil. https://orcid.org/0000-0001-8558-4196.

${ }^{4}$ State University of Montes Claros, Montes Claros, MG, Brazil. https://orcid.org/0000-0002-9406-5918.

${ }^{5}$ State University of Montes Claros, Montes Claros, MG, Brazil.

https://orcid.org/0000-0002-0622-9805.

${ }^{6}$ State University of Montes Claros, Montes Claros, Minas Gerais, Brazil. https://orcid.org/000-003-1238-1042.

${ }^{7}$ State University of Montes Claros, Montes Claros, Minas Gerais, Brazil.

https://orcid.org/0000-0003-1513-9390.

${ }^{8}$ Federal University of Uberlândia, Uberlândia, Minas Gerais, Brazil. https://orcid.org/0000-0001-8162-9174.

${ }^{9}$ Shull Seeds Ltda, Ribeirão Preto, São Paulo, Brazil.

https://orcid.org/0000-0003-1697-4048.

${ }^{10}$ State University of Montes Claros, Montes Claros, MG, Brazil.

https://orcid.org/0000-0002-0512-1616.

*Corresponding author: ericsson_aerc@yahoo.com.br
}

Recebido para publicação em 11 de abril de 2020. Aceito para publicação em 30 de abril de 2020.

e-ISSN: 2447-6218 / ISSN: 2447-6218. Atribuição CC BY. 


\title{
Padronização de método baseado em PCR e sequenciamento para detecção da presença do gene CP4 EPSPS em Zea mays
}

\begin{abstract}
Resumo
O plantio de cultivares transgênicas no Brasil e no mundo tem crescido e demandado regulamentação legal. O evento transgênico MON8807 é frequentemente encontrado em cultivares de milho comercializadas no Brasil. Esse evento contém em sua construção os genes CP4 EPSPS e Cry3Bb1 que codificam, respectivamente, a tolerância ao herbicida glifosato e resistência a lagartas. Metodologias que permitam o rastreamento de eventos transgênicos são globalmente mandatórias. O objetivo deste trabalho foi padronizar uma metodologia baseada em PCR qualitativo e sequenciamento para detecção do gene CP4 EPSPS em Zea mays. Para tal linhagens comerciais de milho transgênico contendo o evento MON88017 e milho convencional foram submetidas ao procedimento de extração de DNA. Foram desenhados oligonucleotídeos para detecção parcial dos genes zeína e CP4 EPSPS. A reação de PCR para detecção das regiões parciais dos genes CP4 EPSPS e zeína (como marcador endógeno da espécie $Z$. mays) foi então realizada. As três linhagens transgênicas de milho testaram positivo para os genes Zeína e CP4 EPSPS, bem como as duas linhagens convencionais testaram negativo para CP4 EPSPS e positivas somente para o gene Zeína. A confirmação da presença das regiões gênicas, os produtos de PCR foram sequenciados e apresentaram 100\% de identidade com sequência dos genes Zeína e CP4 EPSPS depositados no GenBank. Os resultados deste trabalho sugerem a aplicabilidade de um método "in house" para detecção qualitativa do gene CP4 EPSPS em cultivares de milho geneticamente modificado.
\end{abstract}

Palavras-chave: Organismos Geneticamente Modificados. MON8807. Detecção. Milho.

\section{Introduction}

Maize (Zea mays) makes out the largest volume of cereal production in the world. Between the years 2018 and 2019, approximately 17,255.6 million hectares of maize were planted globally (CONAB, 2019). A large variety is observed among maize cultivars, for example, in the harvest of 2016/17 approximately 315 cultivars of corn, of which 214 were transgenic and 101 were conventional, were observed (Pereira-Filho et al., 2016; Tabima-Cubillos et al., 2016). In Brazil, the planting of transgenic cultivars has become very common since the release of commercial strains. Since 2009 the country has been the second-largest producer of transgenic grains in the world. In 2017, there were approximately 50.2 million hectares of maize cultivated, and $31 \%$ of the total land area was used (Cardoso et al., 2018; ISAAA, 2018).

Biotechnology has significantly improved maize cultivars, mainly in relation to agronomic characteristics, such as providing tolerance to aerial and root pest carriers as well as tolerance to herbicides, in particular to glyphosate (Fraiture et al., 2015). The genetic construction used to produce a Genetically Modified Organism (GMO) consists of three regions: a promoter region, an encoding gene, and a terminator region (Wu et al., 2012). The MON88017 event, obtained through the insertion of the CP4 EPSPS and Cry3Bb1 genes was the first product developed and approved by the company, Monsanto (now Bayer), whose 2015/16 season produced 12 cultivars (Cruz et al., 2015).

In Brazil, commercialization of the MON88017 event was approved by the National Technical Commission on Biosafety (CTNBio) in 2010 for planting as well as human and animal consumption (ISAAA, 2018). As a bearer of the Roundup Ready Technology (VT PRO3 ${ }^{\mathrm{TM}}$ ),
MON88017 contains two important expression proteins in the genome: CP4 EPSPS (CP4 5-5-enolpyruvylshikimate-3-phosphate) that originated from Agrobacterium tumefaciens and Cry3Bb1 from Bacillus thuringiensis (ISAAA, 2018). The event presents a genetic construction formed by a regulating region, P-E35S (constitutive promoter of the CaMV $35 S$ gene), a coding region for the CP4 EPSPS protein, and a terminator region, 3'IN (nopaline synthase) (König et al., 2004; Miaw, 2014). As the genes are present in the same segment of DNA and occur in a single locus in the genome, it provided improved efficiency in plant reproduction and allowed the use of molecular markers to identify transgenic genes (Conceição et al., 2006).

As soon as they are released for planting and marketing, all transgenic events must be liable to be detected. In 2003, the Executive Power through the decree no. 4.680/2003, demanded the inclusion of information on the labels of the packed products in bulk or in natura if it contained more than 1\% GMOs (Brasil, 2003).

Compliance with the legislation that regulates the commercialization of food and ingredients containing transgenic components is totally dependent on the sensitivity and reliability of the detection and quantification methods (Conceição et al., 2006). GMOs are characterized by the presence of one or more segments of exogenous DNA, which may or may not provide the expression of new proteins. Thus, GMO detection is focused on exogenous DNA sequences (via PCR-based methods) or transgenic proteins (via immunoassays, ELISA, and Western blot analysis) (König et al., 2004).

Qualitative and quantitative PCR detection methods, which use DNA to monitor genetically modified crops and their derivatives, are widely used mainly for the characteristics or stability of DNA. Protein expression 
may vary depending on the age, variety, environmental conditions, or even the industrial processes used for the manufacturing of oils, syrups, and other products (Cardarelli et al., 2005; Forte et al., 2005; Holst-Jensen et al., 2003).

Real-time quantitative PCR can be used to detect or quantify GMO fractions in food products. On the other hand, qualitative PCR is required for large-scale screening, when large numbers of negative samples are expected, and it is also used for GMO identification (Gašparič et al., 2010). According to Heide et al. (2008), high levels of GMOs in samples produced signals of greater strength than low levels of GMOs. The objective of this study was to standardize a method based on qualitative PCR and sequencing for the detection of the CP4 EPSPS gene in Z. mays.

\section{Materials and Methods}

\section{Obtaining leaf tissue}

Three commercial transgenic maize cultivars with the presence of the event MON88017 were used: $d \mathrm{~kb}$ 230PRO3, dkb 240PRO3, and dkb 177 PRO3, and two conventional maize cultivars: SS7088 and SS8021, kindly provided by Shull Seeds Ltd. The seeds were planted in a substrate Bioplant (Bioplant Blender Agricola Ltd.), kept at ambient conditions of light and temperature, and watered daily. After 10 days, the seedlings were used as a source of leaf tissue for DNA extractions.

\section{DNA extraction}

The DNA of the transgenic and conventional cultivars was extracted from leaf tissue according to the method of Doyle and Doyle (1990) with some modifications. Fifty milligrams of leaves of each cultivar were weighed, transferred to a crucible containing $0.2 \mathrm{~g}$ of autoclaved sand, and macerated with a pistil. During maceration, $2 \mathrm{~mL}$ of $5 \%$ cetyltrimethylammonium bromide (CTAB) buffer, $2 \mu \mathrm{L} / \mathrm{mL}$ of 2-mercaptoethanol, $100 \mathrm{mM}$ TrisHCl (pH 8.0), $1 \mathrm{mg} / \mathrm{mL}$ proteinase $\mathrm{K}, 20 \mathrm{mM}$ EDTA, $100 \mathrm{mM}$ polyvinylpyrrolidone, and $1.4 \mathrm{M} \mathrm{NaCl}$ were added. One milliliters of the macerate obtained were transferred to $2 \mathrm{~mL}$ microtubes and vortexed for 10 seconds, followed by incubation in a water bath at $70^{\circ} \mathrm{C}$ for 1 hour. Every 10 minutes the microtubes were removed from the water bath and agitated again with a vortex mixer to induce rupturing of the cell walls. For DNA extraction, $700 \mu \mathrm{L}$ of chloroform:isoamyl alcohol (24:1) was added to the mixture and homogenized in the vortex mixer for 10 minutes. Then the samples were centrifuged at 14000 rpm for 10 minutes and the supernatant was transferred to a new microtube. To each microtube, $55 \mu \mathrm{L}$ of $10 \%$ CTAB (10\% CTAB, $1.4 \mathrm{M} \mathrm{NaCl})$ and $700 \mu \mathrm{L}$ chloroform:isoamyl alcohol (24:1) was added and homogenized with a vortex mixer for 10 minutes. Then the samples were centrifuged at $14000 \mathrm{rpm}$ for 10 minutes, $700 \mu \mathrm{L}$ of ice cold isopropanol was added to the supernatant, and the mixture was stored at $-20^{\circ} \mathrm{C}$ for 24 hours. After 24 hours, the microtubes were centrifuged at $14000 \mathrm{rpm}$ for 10 minutes and the pellet was washed with $700 \mu \mathrm{L}$ of $70 \%$ ethanol. The pellet containing the nucleic acids was then resuspended in $20 \mu \mathrm{L}$ of TE buffer $(10 \mathrm{~mL}$ Tris-HCl $10 \mathrm{mM} \mathrm{pH}$ 8.0, $2 \mathrm{~mL}$ EDTA $1 \mathrm{mM}$ ) and $1 \mu \mathrm{L}$ of RNase A $20 \mathrm{mg} / \mathrm{mL}$ and stored at $-20^{\circ} \mathrm{C}$. The nucleic acids were quantified by $1.0 \%$ agarose gel electrophoresis and used in PCR reactions.

\section{Design of genetic markers for Zein and CP4 EPSPS genetic regions}

Two pairs of PCR-specific primers were used: (1) Zeo-F/Zeo-R for detection of the Zein maize gene as described by Cardarelli et al. (2005) with modifications (Table 1). The sequences of the primers were confirmed with the sequence of the Zein gene (Genbank accession no. M23537.1); (2) CP4F/CP4R for detection of the CP4 EPSPS gene (transgenic event MON88017) as described by Wu et al. (2012) with modifications (Table 1). The primer sequences were confirmed with the sequence of the CP4 EPSPS gene (Genbank accession no. AB209952.1). All primers were synthesized by GenOne Biotechnologies (Rio de Janeiro, Brazil).

\section{Qualitative PCR for detection of Zein and CP4 EPSPS genes}

The presence of the Zein (an endogenous marker of Z. mays) and CP4 EPSPS genes (a marker for the transgenic event MON88017) was verified with the primers listed in Table 1. The reactions were carried out in a mixture containing $2 \mathrm{x} \mathrm{GoTaq}^{\circledR}$ Green Master Mix (Promega Corporation, USA), $1.5 \mathrm{M} \mathrm{MgCl}_{2}, 10 \mu \mathrm{M}$ of each primer, and $50 \mathrm{ng}$ of DNA with a total reaction volume of $50 \mu \mathrm{l}$. The amplification conditions for both Zein and CP4 EPSPS genes were as follows: an initial cycle of denaturation at $95^{\circ} \mathrm{C}$ for 2 minutes, followed by 35 cycles of denaturation at $95^{\circ} \mathrm{C}$ for 2 minutes, annealing temperature at $60^{\circ} \mathrm{C}$ for 50 seconds, extension at $72^{\circ} \mathrm{C}$ for 1 minute, and final extension for 10 minutes. The amplicons were visualized on a 1.5\% agarose gel, stained with ethidium bromide and documented.

\section{Sequencing of PCR products of Zein and CP4 EPSPS genes}

The PCR products (amplicons of $325 \mathrm{bp}$ and 610 bp corresponding to Zein and CP4 EPSPS, respectively) were sequenced by the Sanger method (Ludwig Biotech Ltd., RS, Brazil - ACTGene Análises Moleculares Ltd.) with the primers described in Table 1 . In order to obtain the amplified sequence, the sequences were aligned with Clustal Omega software (European Bioinformatics Institute - https://www.ebi.ac.uk/Tools/msa/clustalo/) and differences were visualized on electropherograms (Chromas v.2.6.5 - www.technelysium.com.au) and corrected. After obtaining the amplified sequence, it was used to perform BLASTn searches (https://blast.ncbi. 
Cangussu, C. H. C. et al.

nlm.nih.gov/Blast.cgi?PAGE_TYPE=BlastSearch). After the blast searches, the obtained sequences were aligned with BLASTn sequences with Clustal Omega software
(European Bioinformatics Institute (https://www.ebi. ac.uk/Tools/msa/clustalo/).

Table 1 - Sequences and information related to the primers for partial detection of Zein and CP4 EPSPS genes in strains of Zea mays

\begin{tabular}{cccccc}
\hline Gene & Position & Primer & Sequence (5'- 3') & Amplicon Size (PB) & Reference \\
\hline Zein & \multirow{2}{*}{$107-432$} & Zeo-F & TGCATTGTTCGCTCTCCTAG & \multirow{2}{*}{ The } & This study \\
(EU952871.1) & & Zeo-R & GTCGCAGTGACATTGTGGCAT & & \\
CP4 EPSPS & \multirow{2}{*}{$2270-2880$} & CP4-F & CCTCGTCGGGGTCTACGA & & This study \\
$($ KX640115.1) & & CP4-R & CAGCGTGGAGGAGCGAAC & & \\
\hline
\end{tabular}

\section{Results and Discussion}

For this study, commercial transgenic maize seeds that are sold at local markets were purchased in two cities in the north of Minas Gerais State, Brazil. Conventional maize seeds were kindly donated by the company, Sementes Shull Ltd.

The rationale for obtaining DNA samples from leaf tissue was based on previous experience of our research group that tested different protocols that used seeds and distinct DNA extraction methods for $Z$. mays and Glicine max (Campos et al., 2018). In this study, the DNA samples of seedlings of five different maize cultivars extracted with the modified methodology of Doyle and Doyle (1990) presented the characteristic profile of bands with satisfactory quality to proceed with PCR analyses.

Difficulties in the reproducibility of protocols for DNA extraction from plant species that hinder molecular studies that directly depend on the quality of extraction of nucleic acids were discussed in the literature. The presence of polysaccharides, phenols, and secondary compounds, is the main challenge faced in DNA isolation and purification due to the inhibition of Taq polymerase activity in PCR reactions (Mazza and Bittencourt, 2000; Vieira et al., 2010; Sika et al., 2015; Abdel-Latif and Osman, 2017).

To evaluate the quality of the extracted DNA and to genetically confirm the $Z$. mays species among analyzed samples, the Zeo-R and Zeo-F primers were designed (Table 1).

The Zein gene is described in the literature as a marker of $Z$. mays. The full or partial gene regions have been used for the construction of primers for genotypic confirmation of Z. mays (Meyer, 1999; Höhne et al., 2002; Matsuoka et al., 2002; Yamaguchi et al., 2003; Cardarelli et al., 2005; Nascimento et al., 2010; Dinon et al., 2011; Wu et al. , 2012). In this study, partial region primers were designed for the Zein gene based on the gene sequence deposited in Genbank (accession number EU952871). The regions comprising the nucleotides 107 and 439 were chosen for the design of the primers. The PCR reaction for Zein gene detection proved to be positive for the three analyzed DNA samples of transgenic $Z$. mays, since the expected fragment of 325 bp was amplified (Figure 1). An amplicon of the same size was also obtained for the two DNA samples of non-transgenic Z. mays (data not shown).

PCR-based screening methods aimed at detecting genetic elements commonly used in genetically modified plants are important tools for the detection of food, feed, and transgenic seeds samples. The CP4 EPSPS gene is present in a large number of transgenic plants, including Z. mays (Anklam et al., 2002; Matsuoka et al., 2002; Heck et al., 2005; Marmiroli et al., 2008; Vidal et al., 2015).

In order to establish an 'in-house' method for the detection of the CP4 EPSPS gene in transgenic maize, the primers CP4-F and CP4-R were designed (Table 1). The nucleotide sequence corresponding to the CP4 EPSPS gene was obtained from GenBank (access no. KX640115.1). The regions that comprise the nucleotides 2270 and 2880 of the CP4 EPSPS gene were chosen for the design of the primers. The PCR reaction performed for detection of the CP4 EPSPS gene among the three transgenic maize samples, was positive, once the expected fragment of 610 bp was amplified and there was no amplification for the two conventional maize samples (Figure 1).

Several studies have described the PCR method as fast and safe for the identification of transgenic maize through the use of specific primers (Hernández et al., 2003; James et al., 2003; Germini et al., 2004; Onishi et al., 2005; Kim et al., 2006). According to Michelini et al. (2008) and Zhang and Guo (2011), PCR is the most widely used technique for CP4 EPSPS gene detection in maize cultivars, owing to its high sensitivity, genetic stability, and presence in different cultivars.

According to Holst-Jensen et al. (2012) and Broeders et al. (2012), the use of this method to identify different types of maize with primers specific for CP4 EPSPS, $B a r, \operatorname{Cry} 1 A(b)$, and/or Pat genes is of great importance, 
because these genes are present in a variety of cultivars

of maize and soya worldwide.

Figure 1 - Detection of Zein and CP4 EPSPS genes by the PCR method on 1.5\% agarose gel.

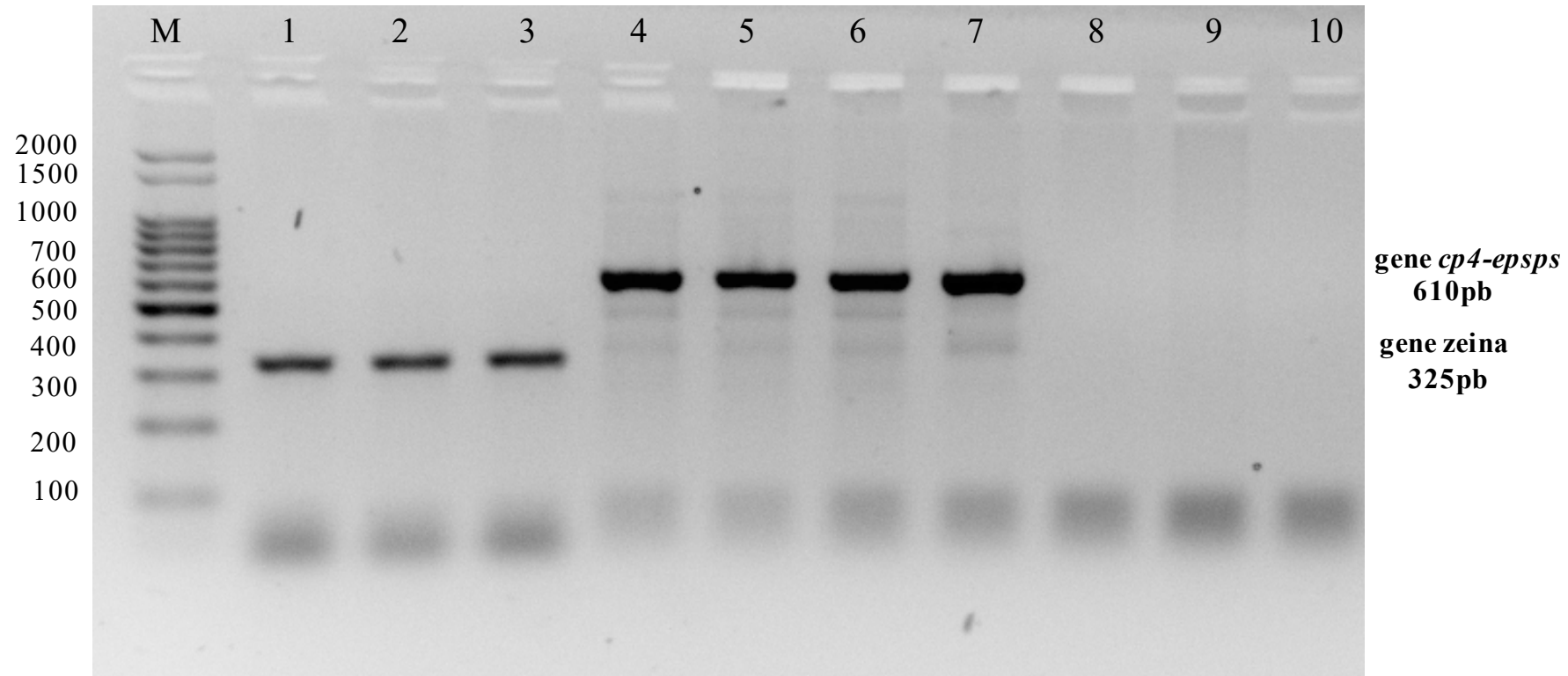

M: marker of molecular mass 100pb (Ludwig Biotecnologia). The Zein gene amplicon of 325 pb amplified in samples 1 to 3: Line 1: dkb230PRO3, Line 2: dkb 240PRO3 and Line3 dkb 177PRO3. The CP4 EPSPS gene amplicon of 610pb amplified in samples 4 to 7: Line 4: dkb230PRO3, Line 5: dkb 240PRO3, Line 6: dkb 177PRO3 and Line 7: dkb177PRO3 (positive control). Line 8: SS7088 and Line 9: SS8021, two conventional cultivars did not present the CP4 EPSPS amplicon as expected. Line 10: sterile water (negative control).

Milavec et al. (2014) showed that using pairs of primers for regulatory regions or inserted genes are more important for obtaining an effective transgenic screening assay. Matsuoka et al. (2002) developed a method using multiple pairs of DNA primers (including genic regions, promoters or terminators) to effectively identify transgenic events.

James et al. (2003) were able to detect transgenic soybeans with multiplex PCR analysis using three pairs of primers specific for the CP4 EPSPS gene, 35S promoter, and NOS terminator, along with two pairs of primers specific for soy targeting soy lecithin and $\beta$-actin genes. The procedure was able to distinguish the non-transgenic soybeans from transgenic soybeans with certainty.

Forte et al. (2005) developed a molecular screening method through multiplex PCR and amplification of specific sequences of soybeans or the $35 \mathrm{~S}$ promoter and NOS terminator for the detection of transgenic events. Nikolić et al. (2008) investigated triplex PCR methods for the identification of the lecithin and Zein genes, through the amplification of the $35 \mathrm{~S}$ promoter and NOS terminator for the detection of genetically modified soya and maize, further illustrating the effectiveness of the methodology.

Although PCR amplification of the Zein and CP4 EPSPS gene regions was successfully achieved in the transgenic samples analyzed here, we decided to submit the PCR products from one of the three cultivars of transgenic $Z$. mays (dkb 177 PRO3) for sequencing of the amplified region. The rationale for this is based on the objective to establish a robust and reliable methodology for transgenic screening in $Z$. mays cultivars.

Database alignment analysis of the sequenced 325 bp PCR product corresponding to the partial Zein gene (dkb 177 PRO3) proved to be identical (100\% identity) to a cDNA sequence of Zein described in Genbank accession number EU952871.1 (Figure 2).

Similarly, database alignment analysis of the sequenced PCR product of 610 bp corresponding to the partial gene CP4 EPSPS (CP4 EPSPS dkb 177 PRO3) proved to be identical (100\% identity) to a sequence of a transgenic cultivar of $Z$. mays lineage transgenic cultivar NK603 containing the CP4 EPSPS gene described in Genbank (KX640115.1) (Figure 3).

The availability of gene sequences of crops of agronomic value, along with the advancement of genetic sequencing, has made it possible to predict and isolate regulatory regions of any region inserted into a genome, facilitating the screening of transgenic events (Schmutz et al., 2010; Tran and Mochida, 2010). 
Cangussu, C. H. C. et al.

Figure 2 - Alignment of the sequence obtained from the amplicon of $325 \mathrm{bp}$ of the partial Zein gene of the lineage of transgenic maize dkb 177 PRO3 (Zein dkb 177PRO3). The asterisks indicate the identical nucleotides between Zein dkb 177PRO3 and the cDNA of Zein of Zea mays Genbank accession number EU952871.1.

Zein dkb 177PRO3

EU952871.1

Zein dkb 177PRO3

EU952871.1

Zein dkb 177PRO3

EU952871.1

Zein dkb 177PRO3

EU952871.1

Zein dkb 177PRO3

EU952871.1

Zein dkb 177PRO3

EU952871.1

Zein dkb 177PRO3

EU952871.1

Zein dkb 177PRO3

EU952871.1

Zein dkb 177PRO3

EU952871.1

Zein dkb 177PRO3

EU952871.1

Zein dkb 177PRO3

EU952871.1

AAATAGGACCTGCTAGATCAATCGCAGTCCATCGGCCTCAGTCGCACATATCTACTATAC

0

60

13

TATACTCTAGGAAGCAAGGACACCACCGCCATGGCAGCCAAGATGCTTGCATTGTTCGCT

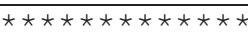

CTCCTAGCTCTTTGTGCAAGCGCCACTAGTGCGACCCATATTCCAGGGCACTTGCCACCA

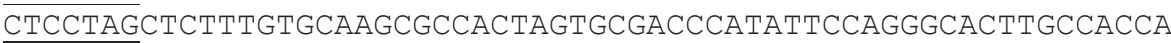

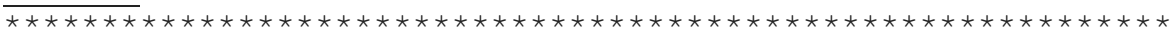

GTCATGCCATTGGGTACCATGAACCCATGCATGCAGTACTGCATGATGCAACAGGGGCTT GTCATGCCATTGGGTACCATGAACCCATGCATGCAGTACTGCATGATGCAACAGGGGCTT GCCAGCTTGATGGCGTGTCCGTCCCTGATGCTGCAGCAACTGTTGGCCTTACCGCTTCAG

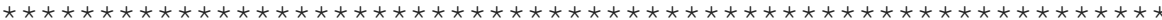

ACGATGCCAGTGATGATGCCACAGATGATGACGCCTAACATGATGTCACCATTGATGATG ACGATGCCAGTGATGATGCCACAGATGATGACGCCTAACATGATGTCACCATTGATGATG

\section{Conclusion}

In this study we designed and tested primers specific to detect zein and CP4 EPSPS genes in Zea mays based on literature and sequences available in Genbank. The qualitative "in house" PCR and sequenced amplicons showed to be a reliable method for tracking the presence of CP4 EPSPS transgenic gene marker in Zea mays due to its robustness, sensitivity, and specificity. Further studies should include the gene marker frequency, others markers used in $Z$. mays and others cultivars as soya and cotton as well as the development of qualitative and quantitative methodologies to confirm the presence of them in transgenic crops or transgenic food.

\section{Acknowledgements}

To Brazilian National Council for Scientific and Technological Development (CNPq), Research Supporting Foundation of Minas Gerais State (FAPEMIG) and Postgraduate Program in Biotechnology of State University of Montes Claros (Unimontes).We would like to thank Editage (www.editage.com) for English language editing.

\section{Authors' contributions}

A.R.E.O.X. and M.A.S.X. conceived designed the study. C.H.C.C., J.S., L.C., L.F.L.C., M.N.B., D.C.F.G. carried out the experiments. C.H.C.C., A.M.E.O., E.S.R., A.R.E.O.X. and M.A.S.X analyzed the data. C.H.C.C., A.R.E.O.X. and M.A.S.X. wrote the manuscript. All authors read and approved the final manuscript. 
Figure 3 - Alignment of the sequence obtained from the amplicon of $610 \mathrm{bp}$ of partial CP4 EPSPS gene of the lineage of transgenic maize dkb 177PRO3 (CP4 EPSPS dkb 177PRO3). The asterisks indicate the identical nucleotides between CP4 EPSPS dkb 177PRO3 and transgenic cultivar of Zea mays L. line NK603 containing the CP4 EPSPS gene described in Genbank accession number KX640115.1.

CP4-EPSPS dkb $177 \mathrm{PRO} 3$ KX640115.1

CP4-EPSPS $177 \mathrm{PRO} 3$

KX640115.1

CP4-EPSPS dkb $177 \mathrm{PRO}$ KX640115.1

CP4-EPSPS dkb $177 \mathrm{PRO} 3$ KX640115.1

CP4-EPSPS dkb $177 \mathrm{PRO} 3$ KX640115.1

CP4-EPSPS dkb $177 \mathrm{PRO} 3$ KX640115.1

CP4-EPSPS dkb $177 \mathrm{PRO} 3$ KX640115.1

CP4-EPSPS dkb $177 \mathrm{PRO} 3$ KX640115.1

CP4-EPSPS dkb $177 \mathrm{PRO} 3$ KX640115.1

CP4-EPSPS dkb $177 \mathrm{PRO} 3$ KX640115.1

CP4-EPSPS dkb $177 \mathrm{PRO} 3$ KX640115.1

CP4-EPSPS dkb $177 \mathrm{PRO} 3$ KX640115.1

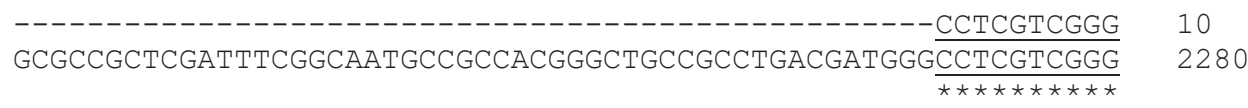

GTCTACGATTTCGACAGCACCTTCATCGGCGACGCCTCGCTCACAAAGCGCCCGATGGGC GTCTACGATTTCGACAGCACCTTCATCGGCGACGCCTCGCTCACAAAGCGCCCGATGGGC

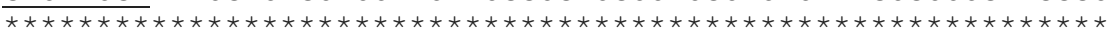

70

CGCGTGTTGAACCCGCTGCGCGAAATGGGCGTGCAGGTGAAATCGGAAGACGGTGACCGT CGCGTGTTGAACCCGCTGCGCGAAATGGGCGTGCAGGTGAAATCGGAAGACGGTGACCGT

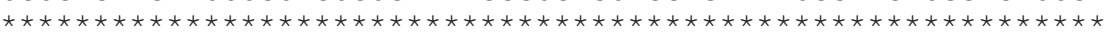

CTTCCCGTTACCTTGCGCGGGCCGAAGACGCCGACGCCGATCACCTACCGCGTGCCGATG CTTCCCGTTACCTTGCGCGGGCCGAAGACGCCGACGCCGATCACCTACCGCGTGCCGATG

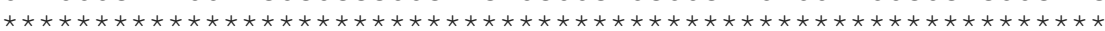
GCCTCCGCACAGGTGAAGTCCGCCGTGCTGCTCGCCGGCCTCAACACGCCCGGCATCACG

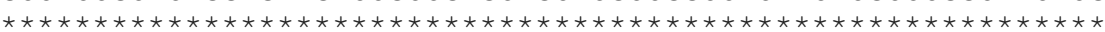

ACGGTCATCGAGCCGATCATGACGCGCGATCATACGGAAAAGATGCTGCAGGGCTTTGGC ACGGTCATCGAGCCGATCATGACGCGCGATCATACGGAAAAGATGCTGCAGGGCTTTGGC

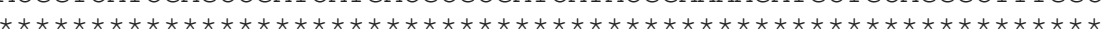

GCCAACCTTACCGTCGAGACGGATGCGGACGGCGTGCGCACCATCCGCCTGGAAGGCCGC GCCAACCTTACCGTCGAGACGGATGCGGACGGCGTGCGCACCATCCGCCTGGAAGGCCGC

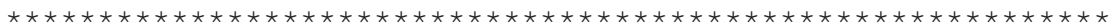

GGCAAGCTCACCGGCCAAGTCATCGACGTGCCGGGCGACCCGTCCTCGACGGCCTTCCCG GGCAAGCTCACCGGCCAAGTCATCGACGTGCCGGGCGACCCGTCCTCGACGGCCTTCCCG

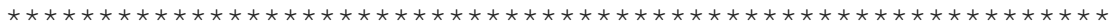

CTGGTTGCGGCCCTGCTTGTTCCGGGCTCCGACGTCACCATCCTCAACGTGCTGATGAAC CTGGTTGCGGCCCTGCTTGTTCCGGGCTCCGACGTCACCATCCTCAACGTGCTGATGAAC

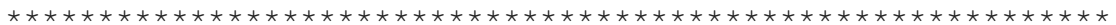

CCCACCCGCACCGGCCTCATCCTGACGCTGCAGGAAATGGGCGCCGACATCGAAGTCATC CCCACCCGCACCGGCCTCATCCTGACGCTGCAGGAAATGGGCGCCGACATCGAAGTCATC

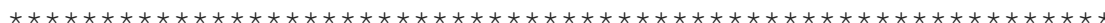

AACCCGCGCCTTGCCGGCGGCGAAGACGTGGCGGACCTGCGCGTTCGCTCCTCCACGCTG AACCCGCGCCTTGCCGGCGGCGAAGACGTGGCGGACCTGCGCGTTCGCTCCTCCACGCTG

\section{References}

Abdel-Latif, A.; G. Osman. 2017. Comparison of three genomic DNA extraction methods to obtain high DNA quality from maize. Plant Methods, 13: 1-9. Doi: https://doi.org/10.1186/s13007-016-0152-4.

Anklam, E.; Gadani, F.; Heinze, P; Pijnenburg, H.; Den Van Eede, G. 2002. Analytical methods for detection and determination of genetically modified organisms in agricultural crops and plant-derived food products. European Food Research and Technology, 214: 3-26. Doi: https://doi.org/10.1007/s002170100415.

Brasil - MAPA - Ministério da Agricultura, Pecuária e Abastecimento. 2003. Decreto No. 4.680/2003: 1-2.
Broeders, S. R. M.; De Keersmaecker, S. C. J.; Roosens, N. H. C. 2012. How to Deal with the Upcoming Challenges in GMO Detection in Food and Feed. Journal of Biomedicine and Biotechnology, 2012: 1-11. Doi: https://doi.org/10.1155/2012/402418.

Campos, L. F. L.; Silva, A. N. M.; David,M. E. D. dos Santos, J.; Cangussu, C. H. C.; Xavier, M. A. S.; Xavier, A. R. E. O. 2018. Eficiência de métodos de extração de DNA de tecido foliar de espécies transgênicas de Glycine max e Zea mays. Retrieved on April, 03, 2019. From: http://www. fepeg2018.unimontes.br/anais/download/3324f215-d852-4a8c-8992b47182cce712. 
Cardarelli, P.; Branquinho, M. R.; Ferreira, R. T. B.; da Cruz, F. P.; Gemal, A. L. 2005. Detection of GMO in food products in Brazil: the INCQS experience. Food Control, 16: 859-866. Doi: https://doi.org/10.1016/j. foodcont.2004.07.010.

Cardoso, L.; Cangussu, C. H. C.; Nogueira, H. S.; dos Santos, J.; Xavier, M. A. S.; de Oliveira, A. M. E.; Albuquerque, C. J. B.; Xavier, A. R. E. O. 2018. Métodos baseados na detecção de DNA para rastreamento de modificações genéticas em cultivares transgênicos de milho e soja. Caderno de Ciências Agrárias, 9: 101-114. [online]. Acesso em 24/04/2020. Disponível em: https://pdfs.semanticscholar. org/7e54/34bb0f28066273f5aaf8e37a27f7ba3efbe3.pdf.

Conceição, F. R.; Moreira, A. N.; Binsfeld, P. C. 2006. Detecção e quantificação de organismos geneticamente modificados em alimentos e ingredientes alimentares. Ciência Rural, 36: 315-324. Doi: https:// doi.org/10.1590/S0103-84782006000100053.

Cruz, J. C.; Pereira-Filho, I. A.; Borghi, E.; Simão, E. P. 2015. Quatrocentas e setenta e sete cultivares de milho estão disponíveis no mercado de sementes do Brasil para a Safra 2015/16. Embrapa Milho e Sorgo, 1: 1-29. [online]. Acesso em 24/04/2020. Disponível em: https:// www.infoteca.cnptia.embrapa.br/infoteca/bitstream/doc/1038512/1/ doc184.pdf.

Dinon, A. Z.; Prins, T. W.; Van Dijk, J. P.; Arisi, A. C. M.; Scholten, I. M. J.; Kok, E. J. 2011. Development and validation of real-time PCR screening methods for detection of cry1A.105 and cry2Ab2 genes in genetically modified organisms. Analytical and Bioanalytical Chemistry, 400: 1433-1442. Doi: https://doi.org/10.1007/s00216-011-4875-9.

Doyle, J. J.; Doyle, J. L. 1990. Isolation of plant DNA from fresh tissue. Focus. 12: 13-15.

Forte, V. T.; Di Pinto, A.; Martino, C.; Tantillo, G. M.; Grasso, G.; Schena, F. P. 2005. A general multiplex-PCR assay for the general detection of genetically modified soya and maize. Food Control, 16: 535-539. Doi: https://doi.org/10.1016/j.foodcont.2004.05.010.

Fraiture, M. A.; Herman, P.; Taverniers, I.; De Loose, M.; Deforce, D.; Roosens, N. H. 2015. Current and new approaches in GMO Detection: challenges and solutions. Biomed Research International, 2015: 1-22. Doi: http://dx.doi.org/10.1155/2015/392872.

Gašparič, M. B.; Tengs, T.; La Paz, J. L.; Holst-Jensen, A.; Pla, M.; Esteve, T; Zel, J.; Gruden, K. 2010. Comparison of nine different real-time PCR chemistries for qualitative and quantitative applications in GMO detection. Analytical and Bioanalytical Chemistry, 396: 2023-2029. Doi: https://doi.org/10.1007/s00216-009-3418-0.

Germini, A.; Zanetti, A.; Salati, C.; Rossi, S.; Forre, C.; S. Schmid, S.; Fogher, C.; Marchelli, R. 2004. Development of a seven-target multiplex PCR for the simultaneous detection of transgenic soybean and maize in feeds and foods. Journal of Agricultural and Food Chemistry, 52: 3275-3280. Doi: https://doi.org/10.1021/jf035052x.

Heck, G. R.; Armstrong, C. L.; Astwood, J. D.; Behr, C. F.; Bookout, J. T.; Brown, S. M.; You, J. 2005. Development and characterization of a CP4 EPSPS-based, glyphosate-tolerant corn event. Crop Science, 45: 329-339. Doi: https://doi.org/10.2135/cropsci2005.0329.

Heide, B. R.; Heir, E.; Holck. A. 2008. Detection of eight GMO maize events by qualitative, multiplex PCR and fluorescence capillary gel electrophoresis. European Food Resesarch and Technology, 227: 527535. Doi: https://doi.org/10.1007/s00217-007-0751-4.

Hernández, M.; Rodríguez-Lázaro, D.; Esteve, T.; Prat, S.; Pla, M. 2003. Development of melting temperature-based SYBR ${ }^{\mathrm{TM}}$ Green I polymerase chain reaction methods for multiplex genetically modified organism detection. Analytical Biochemistry, 323: 164-170. Doi: https://doi. org/10.1016/j.ab.2003.07.015.
Höhne, M.; Santisi, C. R.; Meyer, R. 2002. Real-time multiplex PCR: an accurate method for the detection and quantification of 35S-CaMV promoter in genetically modified maize containing food. European Food Research and Technology, 215: 59-64. Doi: https://doi.org/10.1007/ s00217-002-0503-4.

Holst-Jensen, A., S. B. Rønning, A. Løvseth and K. G. Berdal. 2003. PCR technology for screening and quantification of genetically modified organisms (GMOs). Analyticaland Bioanalytical Chemistry 375: 985-93. [online]. Acesso em 24/04/2020. Disponível em: https://link.springer. com/content/pdf/10.1007/s00216-003-1767-7.pdf.

Holst-Jensen, A., Y. Bertheau, M. de Loose, L. Grohmann, S. Hamels, L. Hougs, D. Morisset, S. Pecoraro, M. Pla, M. Van den Bulcke and D. Wulff. 2012. Detecting un-authorized genetically modified organisms (GMOs) and derived materials. Biotechnology Advances, 30: 1318-35. Doi: https://doi.org/10.1016/j.biotechadv.2012.01.024.

ISAAA, 2018. Event Name: MON88017. Retrieved on April, 04, 2019. From: http://www.isaaa.org/gmapprovaldatabase/event/default. asp?EventID $=94$.

James, D.; Schmidt, A. M.; Wall, E.; Green, M.; Masri, S. 2003. Reliable detection and identification of genetically modified maize, soybean and canola by multiplex PCR analysis. Journal of Agricultural and Food Chemistry, 51: 5839-5834. Doi: https://doi.org/10.1021/jf0341159.

Kim, J. H.; Song, H. S.; Heo, M. S.; Lee, W. Y.; Lee, S. H.; Park, S. H.; Park, H. K.; Kim, M. C.; Kim, H. Y. 2006. Detection of eight different events of genetically modified maize by multiplex PCR method. Food Science and Biotechnology, 15: 148-151. [online]. Acesso em 24/04/2020. Disponível em: http://www.koreascience.or.kr/article/ JAKO200609905801382.page.

König, A.; Cockburn, A.; Crevel, R. W. R.; Debruyne, E.; Grafstroem, R.; Hammerling, U.; Kimber, I.; Knudsen, I.; Kuiper, H. A.; Peijnenburg, A. A. C. M.; Penninks, A. H.; Poulsen, M.; Schauzu, M.; Wal, J. M. 2004. Assessment of the safety of foods derived from genetically modified (GM) crops. Food and Chemical Toxicology, 42:1047-1088. Doi: https:// doi.org/10.1016/j.fct.2004.02.019.

Marmiroli, N.; Maestri, E.; Gullì, M.; Malcevschi, A.; Peano, C.; Bordoni, R.; De Bellis. G. 2008. Methods for detection of GMOs in food and feed. Analytical and Bioanalytical Chemistry, 392: 369-384. Doi: https:// doi.org/10.1007/s00216-008-2303-6.

Matsuoka, T.; Kuribara, H.; Takubo, K.; Akiyama, H.; Miura, H.; Goda, Y.; Kusakabe, Y.; Isshiki, K.; Toyoda, M.; Hino, A. 2002. Detection of recombinant DNA segments introduced to genetically modified maize (Zea mays). Journal of Agricultural and Food Chemistry, 50:2100-2109. Doi: https://doi.org/10.1021/jf011157t.

Mazza, M. C. M.; Bittencourt, J. V. M. 2000. Extração de DNA de tecido vegetal de Araucaria angustifolia (Araucariaceae). Boletim de Pesquisas Florestais, 41:12-17. Disponível em: https://www.alice.cnptia.embrapa. br/bitstream/doc/280588/1/mazza.pdf.

Meyer, R. 1999. Development and application of DNA analytical methods for the detection of GMOs in food. Food Control, 10:391-399. Doi: https://doi.org/10.1016/S0956-7135(99)00081-X.

Miaw, C. S. W.; Amâncio, G.C.S.; Madeira, J. E. G. C.; Souza, S. V. C. 2014. Métodos para detecção de soja Roundup Ready ${ }^{\circledR}$ em grãos e produtos de soja por reação em cadeia da polimerase: revisão e análise crítica das práticas de validação. Revista do Instituto Adolfo Lutz, 73:9-25. Doi: https://doi.org/10.18241/0073-98552014731585.

Michelini, E.; Simoni, P.; Cevenini, L.; Mezzanotte, L.; Roda, A. 2008. New trends in bioinalitical tools for the detection of genetically modified organisms: an update. Analytical and Bioanalytical Chemistry, 392: 355-367. Doi: https://doi.org/10.1007/s00216-008-2193-7. 
Milavec, M.; Dobnik, D.; Yang, L.; Zhang, D.; Gruden, K.; Žel, J. 2014. GMO quantification: valuable experience and insights for the future. Analytical and Bioanalytical Chemistry, 406: 6485-6497. Doi: https:// doi.org/10.1007/s00216-014-8077-0.

Nascimento, V. E.; Pinho, E. V. R. V.; Pinho, R. G. V.; Santos, B. C.; Pereira, E. M.; Júnior, A. D. N. 2010. Especificidade e sensibilidade da técnica de PCR para detecção de milho geneticamente modificado. XXVIII Congresso Nacional de Milho e Sorgo - Goiânia: Associação Brasileira de Milho e Sorgo. CD-rom. Retrieved on September 15, 2019. From: http://abms.org.br/eventos_anteriores/cnms2010/trabalhos/0361.pdf.

Nikolić, Z.; Milošević, M.; Vujaković, M.; Marinković, D.; Jevtić, A.; Balešević-Tubić, S. 2008. Qualitative triplex PCR for the detection of genetically modified soybean and maize. Biotechnology \& Biotechnological Equipment, 22: 801-803. Doi: https://doi.org/10. 1080/13102818.2008.10817556.

Onishi, M.; Matsuoka, T.; Kodama, T.; Kashiwaba, K.; Futo, S.; Akiyama, H.; Maitani, T.; Furui, S.; Oguchi, T. Hino, A. 2005. Development of a multiplex polymerase chain reaction method for simultaneous detection of eight events of genetically modified maize. Journal of Agricultural and Food Chemistry, 53: 9713-9721. https://doi.org/10.1021/jf0515476.

Pereira-Filho, I. A.; Borghi, E. 2016. Mercado de sementes de milho no Brasil: safra 2016/2017. Embrapa Milho E Sorgo, 202: 1-28. [online]. Acesso em 24/04/2020. Disponível em: https://www.infoteca.cnptia. embrapa.br/infoteca/bitstream/doc/1060346/1/doc2021.pdf.

Schmutz, J., Cannon, S. B.; Schlueter, J.; Ma, J.; Mitros, T.; Nelson, W.; Hyten, D. L.; Song, Q.; Thelen, J. J.; Cheng, J.; Xu, D.; Hellsten, U.; May, G. D.; Yu, Y.; Sakurai, T.; Umezawa, T.; Bhattacharyya, M. K.; Sandhu, D.; Valliyodan, B.; Lindquist, E.; Peto, M.; Grant, D.; Shu, S.; Goodstein, D.; Barry, K.; Futrell-Griggs, M.; Abernathy, B.; Du, J.; Tian, Z.; Zhu, L.; Gill, N.; Joshi, T.; Libault, M.; Sethuraman, A.; Zhang, X. C.; Shinozaki, K.; Nguyen, H. T.; Wing, R. A.; Cregan, P.; Specht, J.; Grimwood, J.; Rokhsar, D.; Stacey, G.; Shoemaker, R. C.; Jackson, S. A 2010. Genome sequence of the palaeopolyploid soybean. Nature, 463: 178-183. Doi: https://doi.org/10.1038/nature08670.
Sika, C. K.; Kefela, T.; Adoukonou-Sagbadja, H.; Ahoton, L.; Saidou, A.; Baba-Moussa, L.; Baptiste, L. J.; Kotconi, S. O.; Gachomo, E. W. 2015. A simple and efficient genomic DNA extraction protocol for large scale genetic analyses of plant biological systems. Plant Gene, 1: 43-45. Doi: https://doi.org/10.1016/j.plgene.2015.03.001.

Tabima-Cubillos, L. Y.; Chaparro-Giraldo, A. Trujillo-Güiza, M. L. 2016. Detección de proteínas transgénicas en harinas de maíz comercializadas en Bogotá, Colômbia. Revista de Salud Publica, 18: 470-483. Doi: http://dx.doi.org/10.15446/rsap.v18n3.46923.

Tran, L. S P.; Mochida, K. 2010. Functional genomics of soybean for improvement of productivity in adverse conditions. Functional and Integrative Genomics, 10: 447-462. Doi: https://doi.org/10.1007/ s10142-010-0178-z.

Vidal, N.; Barbosa, H.; Jacob, S.; Arruda, M. 2015. Comparative study of transgenic and non-transgenic maize (Zea mays) flours commercialized in Brazil, focussing on proteomic analyses. Food Chemistry, 180: 288-294. Doi: https://doi.org/10.1016/j.foodchem.2015.02.051.

Vieira, F. A.; Santana, J. A. S.; Santos, R. M.; Fajardo, G. C.; Coelho, G. A. O.; Carvalho, D. 2010. Métodos de extração de DNA e seleção de primers de cpDNA para Ficus bonijesulapensis (Moraceae). Revista Caatinga, 23: 69-74. [online]. Acesso em 24/04/2020. Disponível em: https://periodicos.ufersa.edu.br/index.php/caatinga/article/view/1403.

Wu, H.; Zhang, Y.; Zhu, C.; Xiao, X.; Zhou, X.; Xu, S.; Shen, W.; Huang, M. 2012. Presence of CP4 EPSPS Component in Roundup Ready Soybean-Derived Food Products. International Journal of Molecular Science, 13: 1919-1932. Doi: https://doi.org/10.3390/ijms13021919.

Yamaguchi, H.; Sasaki, K.; Umetsu, H. Kamada, H. 2003. Two detection methods of genetically modified maize and the state of its import into Japan. Food Control, 14: 201- 206. Doi: https://doi.org/10.1016/ S0956-7135(02)00062-2.

Zhang, D.; Guo, J. 2011. The development and standardization of testing methods for genetically modified organisms and their derived products. Journal of Integrative Plant Biology, 53: 539-551. Doi: https:// doi.org/10.1111/j.1744-7909.2011.01060.x. 